\title{
Obesity due to congenital leptin deficiency
}

INSERM

\section{Source}

INSERM. (1999). Orphanet: an online rare disease and orphan drug data base. Obesity due to congenital leptin deficiency. ORPHA:66628

Congenital leptin deficiency is a form of monogenic obesity characterised by severe early-onset obesity and marked hyperphagia. 